\title{
ANTROPOLOGIA: PARA QUE SERVE?
}

ANTHROPOLOGY: WHY IT MATTERS?

ANTROPOLOGÍA: ¿POR QUÉ IMPORTA?

\author{
Lorran Lima (1) $\bowtie$
}

Universidade Federal do Rio Grande do Norte 


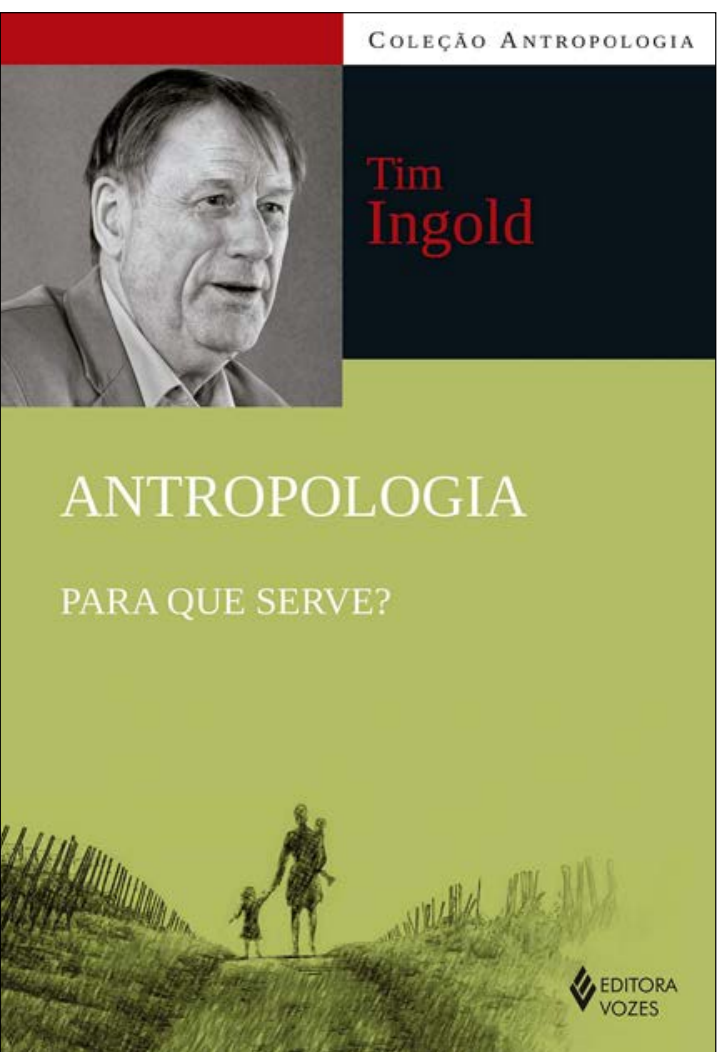

Ingold, T. 2019. Antropologia: para que serve? Petrópolis: Editora Vozes.

Tim Ingold é um antropólogo britânico que desenvolve suas pesquisas levando em consideração as percepções ambiental e ecológica, a relação entre humanos e animais, as tecnologias, a criatividade e o desenvolvimento da antropologia. Autor de muitas obras, ele produziu: "A apropriação da natureza: ensaios sobre ecologia humana e relações sociais" (1986), "Principais debates em antropologia” (1996), "A percepção do meio ambiente: ensaios sobre meios de subsistência, moradia e habilidade" (2000), "Estar vivo: ensaios sobre movimento, conhecimento e descrição" (2011), entre outras.
Esta resenha traz os principais pontos do livro “Antropologia: para que serve?”, publicado no ano de 2019 pela Editora Vozes. Neste livro, Tim Ingold apresenta uma narrativa sobre a história da antropologia enquanto uma ciência que enfrentou colapsos e fragmentações, até ser vista, hoje, como uma disciplina do futuro e da esperança. $\mathrm{O}$ autor demonstra para que a antropologia nos serve, como pode contribuir para um futuro melhor. Com uma visão otimista, ele explica como a antropologia e os antropólogos podem superar um mundo em crise, ao descrever esta área não como uma mera forma de produzir ciência, mas como uma disciplina capaz de valorizar, dar voz e dialogar com os outros, observando a antropologia em sua capacidade de transformar vidas e ressaltando a ética do cuidado, de notar o outro em suas singularidades, tornando-os presentes e possibilitando trocas de experiências.

O autor observa que o antropólogo precisa aprender com o "outro", o que pode possibilitar a construção de um mundo onde haja lugar para todos, capaz de ser construído por todos. Tim Ingold projeta esta disciplina como aquela que pode discutir questões gerais e particulares da sociedade, questões morais, éticas e políticas.

Neste livro, são evidenciados pontos de reflexões que podem ser avaliados e melhorados no fazer antropológico. Em seu primeiro tópico, "Sobre 
levar os outros a sério", o autor descreve a forma de vida humana em sociedade, compreendida como um processo contínuo e coletivo de descobrir como viver. Neste ponto, ele denota que a antropologia abordaria o campo da observação da variedade de como viver, na experiência dos sujeitos no mundo, independente de sua origem, credo, gênero, sexualidade, mas diante de sua subsistência.

Em “Antropologia: para que serve?”, o autor ressalta seu posicionamento sobre a atuação do antropólogo, evidenciando que, muitas vezes, o pesquisador trata os sujeitos como informantes, e não como professores. Ele defende a tese de que o antropólogo precisa superar a objetificação do "outro", deixando de atuar como se estivesse extraindo as memória do interlocutor, devendo, assim, começar a aprender com as pessoas. $\mathrm{O}$ antropólogo defende que precisamos forjar abordagens alternativas ao problema de como viver, o que auxiliará no conhecimento de mundo e de como habitá-lo.

Um gatilho importante no pensamento deste autor é que ele não defende que todas as respostas estejam com os povos ditos "primitivos", muito menos que a culpa recaia sobre os ocidentais, mas que a antropologia possui abordagens baseadas nas experiências vividas pelos diferentes povos que podem servir como aprendizado, sendo passíveis de comparações.
O segundo tópico desenvolvido intitula-se

"Similaridade e diferença", no qual Ingold explica que fomos ensinados a classificar outras culturas como diferentes. Ele lê os antropólogos como defensores de vários mundos, mas posiciona-se contra o pluralismo, avaliando como "equivocado" e perigoso para a disciplina, deixando-nos vulneráveis a reagir às forças globais que trouxeram desigualdades. Ele defende a existência de um único mundo, um mundo de múltiplas diferenças, onde o desafio da antropologia é explicar a singularidade deste lugar.

A antropologia de Ingold é defendida como a ciência que legitima apenas um mundo, mas que não seria o mundo do Ocidente, e sim um lugar de múltiplas diferenças. “[...] Porém, para começar a abordar o desafio, precisamos repensar sobre o que significa dizer que as pessoas são iguais ou diferentes" (p. 20), segundo suas palavras, tarefa que está relacionada à discussão acerca dos conceitos de "natureza" e de "cultura". Para ele, a natureza é algo dotado de sentidos e qualidades essenciais desde seu princípio, sendo estáveis e imutáveis. Por outro lado, a cultura é marcada por suas distinções e particularidades. Ele, assim, define que a diferença entre natureza e cultura marca uma dicotomia que se faz presente nas discussões antropológicas e no mundo.

No entanto, o autor propõe não observar a dicotomia de natureza e cultura como respostas, 
mas sim como perguntas: "a questão da natureza é: em que aspectos os seres humanos são semelhantes? O que os leva a fazer coisas praticamente da mesma maneira? E a questão da cultura é: em que aspectos os seres humanos se diferenciam? Por que eles fazem coisas de formas distintas?" (p. 22). Diante do exposto, ele não acredita na premissa de que os humanos nascem unidos pela natureza e separados pela cultura, mas propõe que isso seja observado de outra forma, na perspectiva de que a diferença seja o elo de união. $\mathrm{O}$ autor diz que precisamos observar o mundo enquanto um campo de variações históricas infinitas e em constante desenvolvimento.

Na terceira sessão, "Uma disciplina dividida", Ingold primeiramente resgata a história do surgimento da antropologia enquanto ciência; a sua construção como "ciência do homem" e como se desintegrou. Antropólogos físicos estudavam a evolução da anatomia humana; antropólogos sociais e culturais, a evolução das instituições, dos costumes e das crenças. Ingold explica que, no início do pensamento antropológico, o defendido era o progresso evolutivo, isto é, a natureza era compreendida como o "crivo" para a seleção natural do homem. Depois do Holocausto, criou-se um compromisso ético com o princípio de que todos os seres humanos, não importa se vivos no passado, no presente ou no futuro, são iguais em suas capacidades intelectuais e morais.
Após apresentar um breve histórico dos conflitos e das divisões dentro da própria ciência, Tim Ingold atribui a constante fragmentação como um dos fatores para que a antropologia seja observada por muitos como uma disciplina em ruínas.

No quarto tópico, "Repensando o social", o autor argumenta que a antropologia social foi concebida como o estudo comparativo das formas de vida encontradas nas sociedades, entendendo as relações sociais como constituídas e mantidas por performance, chamada de tese da complementaridade, segundo a qual "pessoa e organismo, respectivamente, o ser social e o indivíduo biológico, são como duas partes complementares do ser humano que, juntas, formam o todo" (p. 56). Ele, assim, caracteriza os seres humanos como biossociais, não por serem produtos de genes e da sociedade, mas porque produzem continuamente a si mesmos, e uns aos outros, como as criaturas vivas que são, não sendo duas coisas, mas uma só.

No quinto e último tópico do livro, "Antropologia para o futuro", Ingold espera convencer o leitor sobre a importância da antropologia enquanto a disciplina que está posicionada para aplicar o conhecimento da experiência humana. Porém, segundo ele, a disciplina precisa superar obstáculos, entre eles a sua autoapresentação como a disciplina que "faz" a cultura, compreendendo que a cultura não deve ser apresentada enquanto mercadoria. $\mathrm{O}$ autor ressalta a 
discussão sobre antropologia x etnografia, alegando ser mais um ponto que impede que os antropólogos sejam ouvidos, defendendo que, ao dissociar os objetivos da antropologia dos da etnografia, outros caminhos de diálogos apareceriam, exemplificando, ao falar das artes, teatro, música, dança, arquitetura, história e outras ciências. Esta preocupação do autor é também demonstrada no artigo "Anthropology is not Ethnography” (Ingold 2011), onde defende que a antropologia é um estudo com pessoas, e não de pessoas, já que convencionalmente associamos a etnografia ao trabalho de campo e à coleta de dados, e a antropologia com a teoria e a análise dos dados.
O autor argumenta que, mesmo desconsiderando os obstáculos apresentados no texto, a antropologia ainda tem um árduo caminho a percorrer para corrigir os mal-entendidos que assolam a sua imagem pública, defendendo que a disciplina precisa se reestabelecer enquanto única, encontrando um acordo entre a antropologia biofísica e sociocultural.

Tim Ingold defende uma antropologia especulativa e experimental, descritiva e analítica, com o potencial de transformar vidas, considerando que a verdadeira contribuição dela não está em sua produção teórica, mas em sua capacidade de transformar vidas.

\section{REFERÊNCIA}

Ingold, T. 2011. Epilogue: “Anthropology is not Ethnography”, in Being alive. Editado por T. Ingold, pp. 229-243. Routledge: London and New York. 